\title{
Implementation of Measures and Objectives of School-Based Management Policies at Junior High Schools in Donggala Regency
}

\author{
Rismawati ${ }^{1}$, Juraid Abd. Latief ${ }^{1}$, Muh. Nawawi ${ }^{1}$, Intam Kurnia ${ }^{1}$ \\ rismawatitadulako@gmail.com \\ ${ }^{1}$ Faculty of Social Science and Political Science, Tadulako University, Indonesia
}

\begin{abstract}
One of the development priorities is the strategy of decentralization by granting the regions the fullest possible autonomy to administer and handle government affairs within the context of the Unitary State of the Republic of Indonesia, Today, many new models and principles of management have been used, especially in the business world, to be implemented in the education world later on. School-based management, where policy enforcement operates linearly from policy decisions, implementers and public policy results, is one of the models adopted. The application of the Van Meter and Van Horn Model Policy explains that many interrelated variables affect policy efficiency, one of which is the criteria and policy priorities / steps and policy targets that are the metrics used in this analysis, Technique used in this thesis is a qualitative research methodology with a system of descriptive analysis. The aims and priorities of the MBS program have received a favorable feedback from the education unit based on the study outcomes, but the reaction and level of public awareness have not been ideal. This is due to the lack of socialization in educational units, notably at junior high school level, where expectations and targets have been developed and the policy success can be assessed, although it cannot be a certainty that the policy goals will be accomplished. If there is no engagement from authorities or individuals or groups of individuals who are responsible for enforcing public policy at the level of regional government.
\end{abstract}

Keywords: Implementation, Policy, SBM

Received: December 20, 2020

Revised: December 26, 2020

Accepted: January 2, 2021

\section{Introduction}

A policy that stressed the centralist control of the state was the New Order regime (Firnas, 2016). In all fields, the reform era has brought about drastic reforms, characterized by the issuing of a variety of laws that have provided some great and broad recognition (Frenki, 2011). In an increasingly democratic socio-political background, the growth and outcomes of the education sector in the regions must be egalitarian in the sense that without exception, it is capable of being "belonging" to all sectors of society (Hayat, 2018).

The strategy of decentralization by allowing regions the widest possible autonomy to administer and handle government affairs within the context of the Unitary State of the Republic of Indonesia is one of the development priorities carried out in the second constitutional amendment (Akbal, 2017). Education decentralization means the transition to areas with influence and greater jurisdiction to make preparations and to make their own decisions in order to solve the problems facing education (Harahap, 2016).

Through the decentralization of education, Hadiyanto said, it is hoped that the key problems of education, namely quality, equity, importance, performance and management problems, can be solved (Masnun \& Iyus, 2019), The provision of autonomy for autonomous education 
is thus, one of the government's attempts to enhance the quality of education, so that schools can freely allocate capital according to priority needs and make schools more receptive to local environmental needs (Hakim, 2016).

Today, many new models and principles of management have been used, especially in the business world, to be implemented in the education world later on. School Based Management is one of the frameworks embraced (Pasandaran, 2016), Wohlstetter and Mohrman argued that schools have four significant aspects that are concentrated or granted control. Next the authority to make choices. Second, experience and knowledge. Fourth, the evidence that schools use in order to make decisions. Fourth, performance awards that must be managed by each school (Murni, 2019). In addition, a disaster learning process is typically necessary, and even those living in areas not impacted by natural disasters highlight the need to learn about disaster prevention and preparedness (Rajindra et al., 2019)

The participation of the parents of students and the society in the adoption of character education is one aspect of educational change, which is also facilitated by a conducive atmosphere and community life practices that are also role models for students in their everyday attitudes and actions (Silalahi \& Aritonang, 2019), School-based management (SBM) is a model of education management which gives schools greater power to independently manage their schools (Firdianti, 2018), It is the existence of SBM. As well as the much-needed community partnership to deal with refugee concerns and emergency response (Wekke et al., 2019)

Conceptually, by putting schools as the primary unit of change, SBM is understood as an alternate formal option for handling a decentralized curriculum delivery system. This definition positions the transfer of policymakers' power as the most fundamental factor in enhancing the consistency of educational results (Pasaribu, 2017). In accordance with the introduction of the SBM policy in the Donggala Regency, the number of junior high schools in Donggala is 94, based on data from the Office of Education and Culture. There are 88 public-status junior high schools and six private-status junior high schools. According to the study of the ability of each kindergarten, the SBM issue can be seen from its magnitude. The status of Donggala schools especially junior high schools, varies greatly in terms of efficiency, school location and community engagement. School certificates vary from highly established schools to schools that are very disadvantaged, from urban cities to rural areas. Such scenarios appear to be a difficult topic in the application of SBM.

The above study indicates that the government of the Donggala Regency is experiencing obstacles in the running of government wheels, especially in the education sector, this situation also hinders the implementation of the SBM policy at Donggala Regency junior high schools as a result of which the implementation of the SBM policy at Donggala Regency junior high schools has not been maximized. In this analysis, the focus of the thesis is the public policy component, which is part of public policy itself.

\section{Literature Review}

The progress or lack in public policy adoption is profoundly affected by policy implementers (Robby \& Tarwini, 2019), According to William N. Dunn, there are steps that are passed in the public policy process, including the following: 1) Agenda Formulation Phase, 2) Policy Formulation Phase, 3) Policy Introduction Phase, 4) Policy Execution Phase, 5) Policy Assessment Phase (Christianingrum \& Djumiarti, 2019), As a political and administrative process, Grindle presents the implementation model as (Rahmadanita et al., 2018).

This method of compliance analysis is an abstraction of the embodiment of policies and is fundamentally performed to achieve high efficiency in policy implementation that takes place 
in the interaction of multiple variables. This paradigm presupposes that the application of legislation runs linearly through government decisions, implementers and the success of public policy. This model explains that many interrelated influences, namely interrelated variables, affect policy efficiency: (1) Criteria and policy goals/measures and policy objectives, (2) Tools, (3) characteristics of implementing organizations, (4) attitudes of implementing organizations, (5) coordination and implementation practices between relevant organizations, (6) social, economic and political climate (Kurniawan et al., 2018), The first predictor, namely the size and policy priorities, would be the focal point for this report.

With regard to understanding policy implementation, Van Meter and Van Horn argue that the execution of policies requires all activities by public and private entities or organisations which are aimed at achieving the goals set out in previous policy decisions. This entails both one-time attempts to turn policies into organizational environments and continuous efforts to implement the significant and minor improvements demanded by policy decisions (Van Meter \& Van Horn, 1975)

The execution of policies is based on steps taken by the government, private organisations or people to accomplish the aims set out in a prior policy decision. These activities are carried out in an attempt to convert decisions into trends or efforts which as outlined in some policy decisions, are then carried out in order to create adjustments, both major and minor.

Van Meter and Van Horn suggest that expectations and policy priorities have a very significant role in evaluating the mechanism of policy enforcement. Standards and priorities are essential considerations, since the basic objectives of a policy action can be explained from each of these. In conjunction with them a critical point in the study is our main interest in the conditions that decide metrics. Essentially, the success metrics measure the degree to which the standards and priorities of the strategy are realized. The overarching priorities of the policy action are expanded on by criteria and targets. They go beyond the generalities of the regulatory text and include clear and specific criteria for measuring the success of the initiative (Van Meter \& Van Horn, 1975).

From the above description, it can be seen that the key variables that are relevant in the study of policy enforcement are the natural and objective variables. The implementer will work to meet the targets outlined in the policy before implementing the policy, and these goals will be converted into measurable standards to assess the policy's success. The more straightforward and observable the policy priorities are the easier it would be for policy targets to be realized by implementers.

\section{Methods}

The method used in this study is a qualitative research technique with a method of descriptive interpretation, which is a template that makes it easier for researchers to register, map and follow the event process. At the First Middle School in Donggala Regency, this study took place.

As for the key informants, the Secretary of the Office of Education and Culture of the Donggala Regency, the Director of the Division of Staff Growth of the Office of Education and Culture of the Donggala Regency, the Head of the SMP, and the supervisors of the school. The set of data used in this research was divided into three, including in-depth strategies for interviews, observation techniques and record study.

\section{Results and Discussion}

This research explores the SBM policy, which is a management model that provides schools with greater control and promotes decision-making involvement including school 
stakeholders such as teachers, pupils, principals, employees, parents of students, and school program-related populations so that the sense of belonging of the school population will improve the sense of responsibility and dedd

It is possible to define the goals of the implementation of the MBS policy in the Donggala Regency by defining the objectives of the implementation of the MBS policy through the Strategic Plan (RENSTRA) of the Education and Culture Office of the Donggala Regency for the term 2019 - 2023. College growth strategy in the Donggala Regency at the Education and Culture Office of the Donggala Regency, in the form of medium-term priorities and priorities in the field of junior high school development.

The Education and Culture Office establishes a vision and policy course on the basis of the aforementioned strategic plan, relating to the Regional Apparatus Strategic Plan 2019-2023 for the next five years, as the core of the execution of the MBS policy itself is: 1) The nineyear compulsory basic education program for Smart Indonesia to Donggala Kana Mavali and only one activity is the core of SBM, namely the Provision of Operational School Assistance (BOS) for SMP/MTS and Salafiah Islamic boarding schools and non-Islamic education units for junior high schools, 2) Education Service Management Program, 3) Donggala Kana Mavali Educational Innovation Policy Supporting school institutions and school administration through the introduction of school-based management (SBM) in basic education units (SMP), 4) Quality Management Initiative for Teachers and School Staff, 5) Donggala Kana Mavali Software in Educational Creativity. For more info, the formulation in the next five years of the Strategy Statement and the Policy Advice for the Regional Apparatus, including the following table.

Table 1. Goals, Targets, Strategies, and Local Government Policies Donggala Regency 20192023 Period

\begin{tabular}{|l|l|l|l|l|}
\hline No. & \multicolumn{1}{|c|}{ Goals } & \multicolumn{1}{c|}{ Targets } & \multicolumn{1}{c|}{ Strategies } & \multicolumn{1}{c|}{ Policy } \\
\hline 1. & $\begin{array}{l}\text { Realizing } \\
\text { equitable } \\
\text { education } \\
\text { services in } \\
\text { order to } \\
\text { improve the } \\
\text { quality of } \\
\text { human } \\
\text { resources who } \\
\text { are } \\
\text { competitive, } \\
\text { faithful and } \\
\text { devoted }\end{array}$ & $\begin{array}{l}\text { Carrying out } \\
\text { basic education } \\
\text { services evenly } \\
\text { and with } \\
\text { quality }\end{array}$ & $\begin{array}{l}\text { Improve basic } \\
\text { education } \\
\text { services }\end{array}$ & $\begin{array}{l}\text { Organizing formal } \\
\text { education at all } \\
\text { levels, according to } \\
\text { regional authority }\end{array}$ \\
\cline { 3 - 5 } & $\begin{array}{l}\text { Improve } \\
\text { education } \\
\text { services for all }\end{array}$ & $\begin{array}{l}\text { Organizing non- } \\
\text { formal education }\end{array}$ \\
\cline { 3 - 5 } & $\begin{array}{l}\text { Improve quality } \\
\text { education } \\
\text { services }\end{array}$ & $\begin{array}{l}\text { Providing } \\
\text { scholarships for } \\
\text { high achieving and } \\
\text { underprivileged } \\
\text { students }\end{array}$ \\
\cline { 3 - 5 } & $\begin{array}{l}\text { Increasing the } \\
\text { quantity and } \\
\text { quality of } \\
\text { teaching staff }\end{array}$ & $\begin{array}{l}\text { Improve the } \\
\text { quality of human } \\
\text { resources for } \\
\text { educators and } \\
\text { education }\end{array}$ & $\begin{array}{l}\text { Improving the } \\
\text { Quality of Educators } \\
\text { and Education } \\
\text { Personnel }\end{array}$ \\
\hline
\end{tabular}




\begin{tabular}{|c|c|c|c|c|}
\hline & & $\begin{array}{l}\text { Increasing } \\
\text { educational } \\
\text { facilities and } \\
\text { infrastructure }\end{array}$ & $\begin{array}{l}\text { Improve quality } \\
\text { educational } \\
\text { facilities and } \\
\text { infrastructure }\end{array}$ & $\begin{array}{l}\text { Construction of } \\
\text { quality and } \\
\text { equitable education } \\
\text { facilities }\end{array}$ \\
\hline \multirow[t]{7}{*}{2.} & \multirow{4}{*}{$\begin{array}{l}\text { Realizing the } \\
\text { preservation of } \\
\text { community } \\
\text { cultural values } \\
\text { and the } \\
\text { formation of } \\
\text { customary } \\
\text { institutions }\end{array}$} & \multirow{4}{*}{$\begin{array}{l}\text { The realization } \\
\text { of the } \\
\text { establishment } \\
\text { of customary } \\
\text { institutions to } \\
\text { preserve the } \\
\text { values of } \\
\text { community } \\
\text { culture and } \\
\text { local wisdom }\end{array}$} & \multirow{3}{*}{$\begin{array}{l}\text { Strengthening } \\
\text { the } \\
\text { Understanding } \\
\text { of Cultural } \\
\text { Values in the } \\
\text { community }\end{array}$} & $\begin{array}{l}\text { Increasing the } \\
\text { quantity of Pranata }\end{array}$ \\
\hline & & & & $\begin{array}{l}\text { Preservation and } \\
\text { actualization of } \\
\text { regional cultural } \\
\text { customs }\end{array}$ \\
\hline & & & & $\begin{array}{l}\text { Policy making on } \\
\text { local culture }\end{array}$ \\
\hline & & & $\begin{array}{l}\text { Development of } \\
\text { Cultural } \\
\text { Facilities and } \\
\text { Infrastructure }\end{array}$ & $\begin{array}{l}\text { Encouraging } \\
\text { community } \\
\text { participation in the } \\
\text { provision of cultural } \\
\text { facilities and } \\
\text { infrastructure }\end{array}$ \\
\hline & & & & $\begin{array}{l}\text { Organizing the } \\
\text { formulation of local } \\
\text { cultural wealth } \\
\text { management } \\
\text { policies }\end{array}$ \\
\hline & & & $\begin{array}{l}\text { Developing local } \\
\text { arts and culture }\end{array}$ & $\begin{array}{l}\text { Organizing regional } \\
\text { arts and culture } \\
\text { festivals }\end{array}$ \\
\hline & & & & $\begin{array}{l}\text { Organizing seminars } \\
\text { and cultural } \\
\text { dialogues in order to } \\
\text { revitalize and re- } \\
\text { actualize local } \\
\text { culture }\end{array}$ \\
\hline
\end{tabular}

Source: Education and Culture Office of Donggala Regency 2019

The goals and objectives of the MBS policy program are evident, in line with the findings of an interview with the secretary of the Donggala Regency's Head of Education and Culture Office, which reported that:

"Yeah, with the Head of the Office, the aims and priorities of school-based management strategies have been specifically articulated in order to achieve equal education programs in order to increase the efficiency of human capital”. (KS, 14 August 2019).

The Supervisory Coordinator of the Education and Culture Office of the Donggala Regency voiced a similar viewpoint, as in the quote from the interview, as follows: 
"It has been clearly articulated in my view, but execution in the education unit is still minimal, and yes, the goal is simple, namely that schools be given the power to compile programs in accordance with their vision to be provided to school residents" (HS, 15 September 2019).

Then, from the findings of the Donggala Regency Education Office's tracing of the job plan (RENJA) in the last two years, respectively 2018 and 2019, it was found that there were 13 compulsory nine-year basic education programs at the junior high school level in 2018 (SMP). There are five programs linked to the execution of the strategy of the SBM, namely: 1) Student Performance Review/Assessment, Technical Instruction Paper preparation: School Self Evaluation, School Work Plans, (RKS) School Annual Plans (RKT), School Budget Work Plans (RKAS), School Budget and School Funding Work Plans (RAPBS); 2) In-On-In Monitoring and Evaluation; 3) School Management Coaching; 4) Development and Character Building of students, and, 5) Evaluation of 2013 Curriculum Implementation.

The Education and Culture Office's 2019 task schedule, meanwhile, contains three core components of initiatives and events that help the application of the SBM strategy, namely: (1) The nine year compulsory basic education program, (2) Improving the Quality of Education and Education Personnel, as well (3) Educational Service Management Program.

Meanwhile, of the three activity initiatives, the Curriculum for the Administration of Education Facilities is the program most applicable to the application of the SBM strategy. There are 10 task elements in the nine year mandatory curriculum program. There are relatively few projects among the current initiatives that are specifically related to the application of the SBM Strategy. There are currently three activity initiatives connected to this strategy out of a variety of these activities, the majority being services for strengthening.

It indicates that the Education and Culture Office of the Donggala Regency has formulated the priorities and objectives of the MBS policy in the Strategic Plan and a more comprehensive task plan in the activity schedule, which is very transparent and driven, based on the document data provided and the results of the interview above. It says, in line with Grindel (1991), that: If the priorities and targets that were initially generic in nature have been made more detailed in the action programs and the sum of costs allocated to accomplish these goals, the policy formulation process will continue.

In line with Van Meter Van Horn (1975) argued that: If and only if the scale and goals of the policy are realistic with the socio-culture that occurs at the level of policy implementer, the success rate of policy performance can be calculated. The norms and goals of strategy must be transparent and observable so that they can be realized. There would be different meanings if the requirements and policy priorities are vague, and it is possible to create disagreements between implementation agencies. That is why priorities and objectives must be identifiable and measurable, because if it does not have goals and objectives that are a metric of progress, an implementation would not be effective.

Acceptance or consensus on policy priorities is very critical since the success or failure of the MBS policy would be decided by the implementers. Therefore to figure out whether or not the policy is approved, the answer from the impementors is expected. The interview findings revealed that the education unit's reaction to the priorities and objectives of the MBS policy was very good. This is in line with the findings of the Principal's interview that indicated that: The response was really strong, with the whole teacher board, commission, and group in the school itself. Those in the education unit, for example, respond to this problem in the sense of enhancing the efficiency of human capital in the school itself.

This is in line with the Secretary of the Donggala Regency Education and Culture Office,

Copyright @ 2021, International Journal Papier Public Review, Under the license CC BY-SA 4.0 DOI: https://doi.org/10.47667/ijppr.v2i1.66 
namely:

"They were very excited about having this MBS with the response from multiple education units, Alhamduillah, since the MBS genuinely supported them in carrying out their duties, but it had to be socialized, but there had to be more strengthening ". (KS, 14 August 2019).

One of the core principles of the SBM program is to improve the engagement of school members and the society in order to fulfill the school quality standards or to accomplish the targets of school quality within the context of national education. Therefore the importance of public awareness of the SBM policy's aims and priorities. When anyone is interested in the provision of schooling, it is believed that the individual concerned would feel ownership in order to be responsible for meeting school targets.

The extent of public understanding of the goals and objectives of the SBM policy was still very low, based on the results of interviews on how the population and stakeholders perceived the goals and objectives of the MBS policy in Donggala Regency. This is in line with the fact that one of the informants for the Supervisory Coordinator of the Donggala Regency's Education and Culture Junior High School Office reported that:

"The community's comprehension of SBM policy is still very small, in my view. This is attributed to the lack of group socialization on what SBM is actually about". (HS, 15 Juli 2019)

This was also reiterated in Donggala by educational figures who claimed that:

"The culture itself does not know what School Centered Administration is like. The curriculum providers have not socialized in such a manner that the society does not understand. The group assumes that even though it is a joint obligation, including the state, education providers, and the community, the school is the primary base for the delivery of education" (view of TB in FGD, 13 December 2019).

Based on the findings of the interview above the level of group awareness of the SBM program was caused by the lack of public distribution of information or the lack of socialization carried out by the Education and Culture Office and the Education Team. The Head of the Workforce Growth Division confirmed that this is in line with the conclusions of the interview that:

"Specifically for MBS, there is no socialization, there is technical guidance, but piloting should only be done through BOS socialization or meetings in working groups" (MH, 2 September 2019).

This is equivalent to what was said by one of the Donggala Regency Junior High School Principals who:

"Whereas during the time he became a school principal, he had never been invited to take part in the SBM socialization specifically, unless there was BOS socialization or other trainings, usually SBM material was inserted. We only know what to do, but we are not well understood in depth, we don't know what to do at school". (Tasrifin's view in FGD, S.Pd. 13 December 2019).

The reality that the socialization of the goals and objectives of the MBS policy has not been maximized, this was also strengthened by several informants, namely: Daud, S.Pd (interview in Karya Mukti on 27 July 2019), Hasan, S.Pd. (interview at Gunung Bale office of Education and Culture Office on 15 September 2019), Abd. Syahid, S.Pd., MM. (interview in Kabonga on 12 September 2019). 
The goals and objectives of the MBS program have received a favorable response from the education unit based on the findings of the aforementioned study, but the response and level of public awareness have not been satisfactory. This is due to the lack of socialization performed in education units, especially at the level of junior high school.

\section{Conclusion}

Goals, targets, programs and activities, performance indicators that have been planned both by the Education and Culture Office of Donggala Regency, and education units, namely junior high schools, some of the program activities have touched on the essence of the SBM policy, but programs related to policies have not been realized. SBM. In addition, there are no clear documents to explain the goals and policy principles adopted by the Donggala Regency Education and Culture Office, in particular the application of the SBM policy. This has an impact on education units, including junior high schools, as implementing units with field difficulties in implementing the application of the SBM policy. If expectations and goals have been developed and the policy performance can be measured, the policy objectives can not be assured to be accomplished if there is no effort from leaders or individuals or groups of individuals who are responsible for executing public policies at the level of the regional government.

\section{References}

Akbal, M. (2017). Harmonisasi Kewenangan Antara Pemerintah Pusat dan Daerah Dalam Penyelenggaraan Otonomi Daerah. SUPREMASI: Jurnal Pemikiran, Penelitian Ilmu-Ilmu Sosial, Hukum Dan Pengajarannya, 11(2), Article 2.

Christianingrum, S. I., \& Djumiarti, T. (2019). Implementasi Program Kota Tanpa Kumuh di Kecamatan Semarang Timur. Journal of Public Policy and Management Review, 8(2), 88-105-105.

Firdianti, F. (2018). Implementasi Manajemen Berbasis Sekolah Dalam Meningkatkan Prestasi Belajar Siswa. Gre Publishing.

Firnas, M. A. (2016). Politik Dan Birokrasi: Masalah Netralitas Birokrasi di Indonesia Era Reformasi. JRP (Jurnal Review Politik), 6(1), 160-194.

Frenki, F. (2011). Politik Hukum dan Perannya Dalam Pembangunan Hukum di Indonesia Pasca Reformasi. ASAS, 3(2), Article 2.

Hakim, M. N. (2016). Implementasi Manajemen Berbasis Sekolah Dalam Mewujudkan Sekolah Islam Unggulan. Nidhomul Haq: Jurnal Manajemen Pendidikan Islam, 1(2), 104-114.

Harahap, E. K. (2016). Manajemen Otonomi Pendidikan di Indonesia. Ri'ayah: Jurnal Sosial Dan Keagamaan, 1(02), 137-151.

Hayat, A. (2018). Reformasi Pendidikan Non Formal Untuk Mengurangi Pengangguran di Era Otonomi Daerah; Perspektif Governance. Prosiding Universitas Wiraraja.

Kurniawan, R., Alexandri, M. B., \& Nurasa, H. (2018). IMSTeP: Indonesian Marine Science And Techno Park Implementasi Kebijakan Model Van Meter Dan Van Horn Di Indonesia. Responsive: Jurnal Pemikiran Dan Penelitian Administrasi, Sosial, Humaniora Dan Kebijakan Publik, 1(1), 34-38.

Masnun, M., \& Iyus, A. (2019). Staregi Kepemimpinan Kepala Madrasah dalam Mengimplementasikan Manajemen Berbasis Madrasah. IJEE: Indonesian Journal of Elementary Education, 1(1), Article 1. 
Murni, M. (2019). Manajemen Berbasis Sekolah. Jurnal Mimbar Akademika, 3(2), Article 2.

Pasandaran, S. (2016). Desentralisasi Pendidikan dan Masalah Pemberdayaan Sekolah. Jurnal Ilmu Pendidikan, 11(2), Article 2.

Pasaribu, A. (2017). Implementasi Manajemen Berbasis Sekolah Dalam Pencapaian Tujuan Pendidikan Nasional di Madrasah. EduTech: Jurnal Ilmu Pendidikan Dan Ilmu Sosial, 3(1), Article 1.

Rahmadanita, A., Santoso, E. B., \& Wasistiono, S. (2018). Implementasi Kebijakan Smart Government dalam Rangka Mewujudkan Smart City di Kota Bandung. Jurnal Ilmu Pemerintahan Widya Praja, 44(2), 81-106.

Rajindra, R., Wekke, I. S., Sabara, Z., Samad, M. A., Yani, A., \& Umam, R. (2019). Diversity, Resilience, and Tragedy: Three Disasters in Palu of Indonesia. International Journal of Innovation, 5(2), 16.

Robby, U. B., \& Tarwini, W. (2019). Inovasi Pelayanan Perizinan Melalui Online Single Submission (OSS) Studi Pada Izin Usaha di Dinas Penanaman Modal dan Pelayanan Terpadu Satu Pintu (DPMPTSP) Kabupaten Bekasi. Administratio: Jurnal Ilmiah Administrasi Publik dan Pembangunan, 10(2), 51-57.

Silalahi, E. F., \& Aritonang, E. (2019). Pengaruh Penerapan Pembelajaran Seni Musik Terhadap Karakter Siswa di SMA N.1 Silimakuta. Seminar Nasional Multi Disiplin Ilmu Universitas Asahan, O(0), Article 0.

Van Meter, D. S., \& Van Horn, C. E. (1975). The Policy Implementation Process: A Conceptual Framework. Administration \& Society, 6(4).

Wekke, I. S., Sabara, Z., Samad, M. A., Yani, A., Abbas, T., \& Umam, R. (2019). Earthquake, Tsunami, and Society Cooperation: Early Findings in Palu Of Indonesia Post Disaster. INA-Rxiv. 